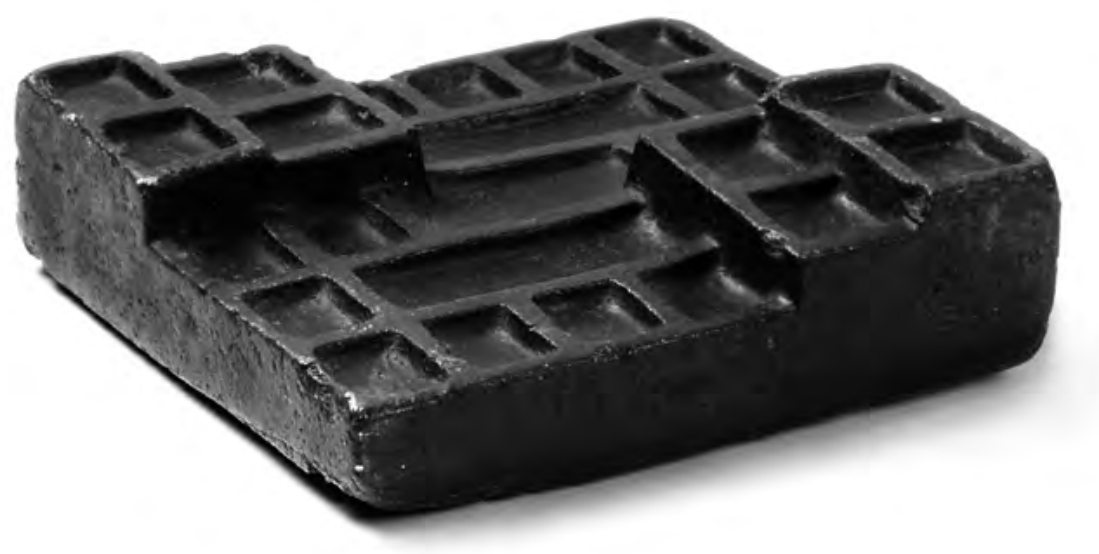

Yupana o modelo arquitectónico de estilo Inca. Piedra tallada y pulida. Colección Museo de Arte de Lima. Donación Memoria Prado. 7,5 x 24,5 x 26,5 cm. Modelando el mundo. Imágenes de la arquitectura precolombina es un regalo publicado por el MALI, Museo de Arte de Lima que muestra todas las maquetas representando edificios, ciudades o paisajes roturados.

\title{
La nube
}

Nuestra obsesión es la de atrapar la sombra, la de generar rincones donde poder producir contrastes, contrastes sobre los que nuestra mirada se pueda posar. Necesitamos la sombra como una tabla de salvación. Nuestra luz es plana. Nuestra obsesión por la sombra nada tiene que ver con la protección solar, con el cobijo, tiene que ver con la intimidad.

Cito de memoria una conversación con Jean Pierre Crousse, que mantuvimos mientras paseábamos por la casa F durante el mes de julio bajo la luz de la panza de burra. Una vivienda unifamiliar de mil doscientos metros cuadrados y dos patios diagonales a distinta altura. Pasillos, rampas y estancias conectadas colmatando una parcela encintada por un muro, mirando hacia dentro. Mucho tiene que ver con la recreación Inca de Puruchuco recuperada, a su manera, por Arturo Jiménez Borja en el año 1959. Singular arqueólogo. La ruina de Puruchuco, y otras tantas construcciones residenciales precolombinas, recogen gran parte de los elementos del discurso contemporáneo peruano. Incluida la captura de la sombra. Construcciones compactas, abiertas hacia dentro y hacia arriba, abrazadas por un muro, escalonadas y gruesas, laberínticas, donde el recorrido justifica el conjunto, más tarde promenade. Como prueba de ello los Incas tallaban pequeñas Yupanas o maquetas en madera o piedra donde se condensaban estas ideas arquitectónicas. Aunque tal vez la formalización de estas ideas sea algo anecdótico frente a la presencia de la luz aplastante.

Regresemos a lo que está arriba, a lo que siempre está arriba. Una nube blanca, opaca, pesada, incómoda, perenne, que oprime durante nueve meses la ciudad de Lima. Da la sensación de que la arquitectura espera avergonzada la llegada del verano para lucirse, para exhibirse durante los tres únicos meses en los que puede verse el sol. Diciembre, enero y febrero. Los arquitectos confiesan esperar al verano para fotografiar sus obras siguiendo los cánones establecidos por el circuito internacional. Sin embargo, la nube es una realidad, una fuente de luz que no genera sombras, donde no existen los contrastes, húmeda. Algo con lo que se convive y se tiene que convivir permanentemente.

Hablo de Lima porque es a partir de Lima desde donde se puede trazar la hoja de ruta de la arquitectura contemporánea del Perú. Ha resultado especialmente complicado descubrir un hilo conductor de la arquitectura peruana para presentarlo en estas páginas. Un pueblo heterogéneo afectado por múltiples influencias. Influencias neocoloniales españolas, y por extensión moriscas, precolombinas indigenistas o neoperuanas, incaicas o preincaicas, Moche, Chimú, Lambayeque, Cupisnique, Lima..., californianas, africanas, japonesas, chinas y centroeuropeas, a través del estilo internacional o el brutalismo que tuvo gran presencia durante los años 70 en la ciudad. Un catálogo de recursos formales y afecciones culturales imposibles de acotar desde un punto de vista estilístico. Un reflejo de su población mestiza. Imprescindible el libro Lima y el Callao de Enrique Bonilla.

No es momento para investigar sobre la búsqueda constante de una identidad impulsada hace 60 años por la Agrupación Espacio de la mano de Luis Miroquesada o de los primeros modernos del 
Perú, el arquitecto y presidente Fernado Belaúnde, Seoane, Agurto, Cron, Williams, Weberhofer, Soyer... y más tarde Ciriani, yendo y viniendo desde París.

Sin embargo, sí tenemos espacio para aglutinar en torno a la nube un posible discurso identitario, todavía en estado larvario. La nube o, dicho de otro modo, los condicionantes físicos, territoriales, comienzan a ser considerados argumentos de proyecto frente a la incorporación de gestos culturales del pasado o importados. La nube permanece pero las culturas van y vienen dejando siempre algo en el camino. Huellas que ha ido recogiendo, hasta ahora, la arquitectura peruana una y otra vez en un esfuerzo permanente y estéril de reconocerse a través de las formas, de un lenguaje propio que nunca se ha consolidado. Parece que se atisba un cambio de referentes.

En este número reunimos en torno a Juvenal Baracco a un conjunto de arquitectos cuyas obras aparentemente no presentan demasiadas coincidencias. Sus resultados son dispares, sin embargo, la pasión y la sensibilidad transmitida por Baracco se reconoce en su actitud. De algún modo Enrique Ciriani también está presente en el rigor y la disciplina de muchos de ellos. Podemos apreciar en las páginas 46 y 47 la evolución de la arquitectura contemporánea marcada desde sus inicios por la UNI, Universidad Nacional de Ingeniería antes Escuela Nacional de Ingenieros, en la que se formaron los primeros modernos, y ampliada ahora por otras universidades como la Universidad Ricardo Palma, la Universidad Peruana de Ciencias Aplicadas, la Pontificia Universidad Católica de Perú, o la Universidad de Lima. Todas en la capital. De ellas han salido gran parte de estos arquitectos. La pasión y la sensibilidad les lleva a desprenderse de los condicionantes formales, simbólicos, tipológicos precedentes para acercarse poco a poco a una realidad propia basada en parámetros estrictamente territoriales, económicos o climáticos donde encuentran sus respuestas. Esta actitud permite convertir un lugar áspero, un presupuesto limitado o la presencia de la nube en una ventaja que puede ofrecer las respuestas más adecuadas a sus necesidades. Son plenamente conscientes de su propia realidad física y esa realidad parece ser el motor de sus decisiones.

Desde rita_continuamos constatando sobre el terreno los planteamientos teóricos y las investigaciones científicas que van apareciendo en esta publicación. Una operación conmutativa entre teoría y práctica, entre la universidad y la calle.

Nota para investigadores:

La recién creada Facultad de Arquitectura de la Universidad de Piura a 980 Kilómetros al norte de Lima acaba de reunir los archivos completos de Enrique Seoane Ros (1915-1980) y Rafael Agurto Calvo (1921-2010). Referentes de la primera modernidad peruana. Oportunidad para completar un capítulo de la Arquitectura Moderna en el Perú. Una historia todavía sin escribir.

Arturo Franco 